\title{
PENERAPAN E-LEARNING DALAM PEMBELAJARAN BAHASA ARAB DI MASA PANDEMI
}

\author{
Ahmad Fadilah Khomsah', Muassomah Muassomah² \\ 1 Universitas Islam Negeri Maulana Malik Ibrahim Malang \\ 2Universitas Islam Negeri Maulana Malik Ibrahim Malang \\ Email: fadilkhomsah@gmail.com ${ }^{1}$, muassomah@bsa.uin-malang.ac.id ${ }^{2}$
}

\begin{tabular}{c|c|c}
\hline Received: Februari 2021 & Accepted: Juni 2021 & Published: Juni 2021 \\
\hline
\end{tabular}

\begin{abstract}
Today's online-based media learning innovations are increasing. In the world of education in Indonesia, there has been a shift in the tradition of learning from school-based offline to online technology-based, as a result of the Covid-19 pandemic. This study examines the application of E-learning in Arabic learning in class X IPS 3 MAN 3 Tulungagung. This study aims to determine the application of the use of E-learning in learning Arabic along with its benefits, driving and inhibiting factors. So that later the problems and shortcomings can be overcome. The method used is descriptive qualitative, data collection using observation, interviews and documentation. The results of this research are obtained first, in its application there are several kinds of onlinebased media used such as Web base learning, Zoom meeting rooms, WhatsApp, Ebook, and Google. Second, the application of Arabic learning during the pandemic was very helpful in overcoming the problems of implementing learning outside the network which was disrupted due to the corona virus outbreak. Third, there are several factors that encourage and hinder the successful implementation of online-based learning such as the internet network, the availability of communication tools, facilitators and control from teachers and parents to students. In addition there are factors that become obstacles, such as the lack of socialization on the use of E-learning, problematic internet networks, inadequate communication tools and lack of control from parents to students.
\end{abstract}

Keywords: Arabic Lessons, E-learning, Online media, Pandemic

\begin{abstract}
Abstrak: Inovasi pembelajaran media berbasis online dewasa ini semakin meningkat. Dalam dunia pendidikan di Indonesia telah mengalami pergeseran tradisi pembelajaran dari offline berbasis sekolah, menjadi online berbasis teknologi, yang diakibatkan pandemi Covid-19. Penelitian ini mengkaji tentang penerapan E-learning dalam pembelajaran bahasa Arab di kelas $X$ IPS 3 MAN 3 Tulungagung. Penelitian ini bertujuan untuk mengetahui penerapan penggunaan Elearning dalam pembelajaran bahasa Arab beserta dengan manfaat, faktor pendorong dan penghambatnya. Sehingga nantinya dari problematika dan kekurangannya itu dapat diatasi. Metode yang digunakan deskriptif kualitatif, pengumpulan data dengan menggunakan observasi, wawancara dan dokumentasi. Hasil penelitian ini diperoleh yang pertama, dalam penerapannya ada beberapa macam media berbasis online yang digunakan seperti halnya Web base learning, Zoom meeting room, WhatsApp, Ebook, dan Google. Kedua, penerapan pembelajaran bahasa Arab di masa pandemi sangat membantu dalam mengatasi problematika pelaksanaan pembelajaran di luar jaringan yang terganggu akibat wabah virus corona. Ketiga, ada beberapa faktor yang mendorong dan menghambat kesuksesan pelaksanaan pembelajaran berbasis online seperti halnya jaringan internet, ketersediaan alat komunikasi, fasilitator dan kontrol dari guru dan orang tua kepada siswa. Selain itu ada faktor yang menjadi penghambat diantaranya seperti kurangnya sosialisasi penggunaan E-learning, jaringan internet yang bermasalah, alat komunikasi yang kurang memadai dan kurangnya kontrol dari orang tua kepada siswa.
\end{abstract}

Kata Kunci: E-Learning, Media Online, Pandemi, Pembelajaran Bahasa Arab 


\section{A. Pendahuluan}

Keberhasilan sebuah pelaksanaan pembelajaran tidak terlepas dari pemilihan penggunaan model dan strategi pembelajaran yang digunakan oleh pendidik dalam mengajar. Kebanyakan saat ini banyak dijumpai pendidik yang masih kurang mengetahui kebutuhan, kondisi dan karakteristik peserta didik yang diajarnya. Ada beberapa indikator mengenai penggunaan program pembelajaran yang efektif dan efisien antara lain; 1) dapat mewadahi peserta didik dalam mencapai kemampuannya 2) memberikan dorongan kepada peserta didik dalam menuntut ilmu, pengetahuan dan keterampilan yang dipelajarinya 3) membuat menarik peserta didik, sehingga materi mudah diingat oleh peserta didik 4) mampu menempatkan materi yang telah diperoleh ke dalam konteks yang sesuai. ${ }^{1}$ Dari pemaparan mengenai indikator-indikator tersebut hal ini menjadikan sebuah tantangan tersendiri bagi seorang pendidik dalam berinovasi maupun berkreasi dalam penggunaan media pembelajaran yang sesuai digunakan oleh siswa terlebih saat ini dalam suasana pandemi covid-19 yang banyak membutuhkan media pembelajaran berbasis digital, siap ataupun tidak siap harus mampu berbenah menyesuaikan zaman. ${ }^{2}$

Teknologi merupakan sarana atau media untuk menyiapkan barang-barang yang dibutuhkan dalam kenyamanan dan kelangsungan hidup manusia. ${ }^{3}$ Definisi teknologi pendidikan sering dikaitkan dengan teori belajar dan pembelajaran. Istilah teknologi pendidikan melingkupi sistem yang digunakan dalam proses pemerolehan dan pengembangan kompetensi manusia atau peserta didik, sedangkan teori belajar dan pembelajaran meliputi proses dan sistem belajar dalam pembelajaran. Dewasa ini peserta didik terbiasa dengan penggunaan teknologi digital dalam mendukung aktivitasnya sehari-hari. Kebanyakan peserta didik lebih berminat dalam mencari informasi melalui komputer dan handphone daripada melalui buku. ${ }^{4}$

Dalam penelitian ini peneliti merujuk dari berbagai jurnal sebagai bahan referensi. Vadhillah dkk., meneliti tentang permasalahan-permasalah yang dihadapi dalam pembelajaran bahasa Arab dalam penelitiannya tersebut banyak mengangkat permasalahan pembelajaran bahasa Arab di kelas atau tatap muka. ${ }^{5}$ Khomsah dan Imron dalam penelitiannya mengkaji tentang kolaborasi

1 Suparman Atwi, “Guru Sebagai Arsitek Pembelajaran Sepanjang Waktu: Mungkin?,” dalam Seminar Universitas Terbuka (Jakarta: Universitas Terbuka, 2013).

2 Meidiana Sahara Riqza dan M. Muassomah, "Media Sosial untuk Pembelajaran Bahasa Arab pada Masa Pandemi: Kajian Kualitatif Penggunaan WhatsApp pada Sekolah Dasar di Indonesia," Alsina: Journal of Arabic Studies 2, no. 1 (2020): 71-94.

3 Wikipedia, "Teknologi," dalam Wikipedia bahasa Indonesia, ensiklopedia bebas, 24 Juni 2021, https://id.wikipedia.org/w/index.php?title=Teknologi\&oldid=18561960.

4 Mohd Aderi Che Noh, Haslina Abdullah, dan Nor Hayati Fatmi Talib, "Knowledge and Learning Teachers Toward The Implementation of Guided Inquiry Approach in Aqidah Curriculum," Al-Hayat: Journal of Islamic Education 3, no. 2 (2019): 126-39.

${ }^{5}$ Syukra Vadhillah, Alimin Alimin, dan Suharmon Suharmon, "Problematika Pembelajaran Bahasa Arab di Madrasah Aliyah Negeri (MAN) Batu Mandi Tilatang Kamang," Arabia 8, no. 1 (2017). 
metode tanya jawab dengan aplikasi kahoot membuat pembelajaran menjadi hidup sehingga pembelajaran menjadi kondusif dan terkendali.6 Kosim dkk, mengkaji tentang penggunaan portal rumah belajar kemendikbud sebagai media pembelajaran daring di tingkatan sekolah dasar.7 Selain itu Hubbard dalam penelitiannya tentang model pembelajaran yang dikolaborasikan dengan penggunaan media pembelajaran memperoleh hasil yang signifikan terhadap pemahaman peserta didik dalam memahami materi yang diajarkan/ disampaikan guru dibandingkan dengan sistem pembelajaran instruksi konvensional. ${ }^{8}$

Dari beberapa referensi di atas terdapat beberapa kekurangan yaitu terkait permasalahan yang dihadapi saat ini mengenai pembelajaran daring yang menggantikan peran pembelajaran di dalam kelas. Dari permasalahan penelitian di atas permasalahan yang dihadapi berbeda dengan kondisi saat ini yang mengharuskan ketersediaan kelas online. Selain itu, penggunaan media berbasis online juga perlu diperhatikan harus disesuaikan dengan kebutuhan dan kondisi siswa agar hasil yang diperoleh dapat maksimal.

Melihat permasalahan saat ini yang diakibatkan oleh covid-19 membuat pembelajaran yang semula dilakukan di dalam kelas menjadi terganggu. Oleh karena itu, agar pembelajaran tetap berlangsung dengan sebagaimana mestinya perlu adanya inovasi dari seorang guru. Pembelajaran berbasis online sebagai solusi yang paling tepat digunakan oleh guru bahasa Arab di MAN 3 Tulungagung agar pembelajaran dapat tetap tersampaikan dengan baik ke setiap peserta didik. Untuk itu, peneliti merasa tertarik terkait dengan penerapan pembelajaran bahasa Arab berbasis online di MAN 3 Tulungagung.

Tujuan dari penelitian ini antara lain; 1) untuk mengetahui penggunaan media pembelajaran berbasis online yang digunakan dalam mengajar bahasa Arab di MAN 3 Tulungagung, 2) faktorfaktor pendorong keberhasilan pembelajaran berbasis online di MAN 3 Tulungagung dan 3) faktorfaktor yang menghambat pembelajaran berbasis online di MAN 3 Tulungagung.

\section{B. Kajian Teori}

\section{Pembelajaran bahasa Arab}

Pembelajaran bahasa Arab merupakan gabungan dari susunan kata pembelajaran dan bahasa Arab. Pembelajaran mempunyai makna suatu usaha yang dilakukan secara sadar/ sengaja dengan harapan yang bersifat positif dalam hal perubahan bentuk perilaku yang disesuaikan dengan

\footnotetext{
${ }^{6}$ Ahmad Fadilah Khomsah dan Muhammad Imron, "Pembelajaran bahasa Arab melalui kolaborasi metode questioning dan media kahoot," Tarbiyatuna: Jurnal Pendidikan Ilmiah 5, no. 1 (2020): 99-118.

7 Nanang Kosim dkk., "Pembelajaran bahasa Arab melalui daring: Problematika, solusi dan harapan," Work From Home, 2020.

8 Philip Hubbard, "Making a Case for Learner Training in Technology Enhanced Language Learning Environments," CALICO Journal 30, no. 2 (31 Mei 2013): 163-78, https://doi.org/10.11139/cj.30.2.163-178.
} 
kondisinya. ${ }^{9}$ Pembelajaran juga mempunyai makna suatu kegiatan yang diadakan untuk menuntun peserta didik. ${ }^{10}$ Selain itu, Oemar Hamalik juga berpendapat bahwasanya pembelajaran merupakan suatu proses yang tersusun secara sistematis yang terdiri dari unsur-unsur manusia, penunjang/ fasilitas, perlengkapan, dan langkah-langkah yang berkaitan dengan tercapainya tujuan pembelajaran.11 Jadi, dapat dikatakan melalui proses pembelajaran akan terbentuk juga pengembangan moral spiritual, keaktifan, dan keterampilan dari peserta didik. Hal tersebut dapat terjadi karena adanya proses interaksi sosial selama pembelajaran dan dari pengalamannya.

Bahasa Arab merupakan suatu disiplin ilmu yang terdiri dari semua aspek kemampuan berbahasa dan unsur-unsur yang terkandung di dalamnya. Intinya, keempat keterampilan berbahasa Arab tersebut tidak berbeda dengan keterampilan bahasa lain pada umumnya. ${ }^{12}$ Sedangkan untuk pembelajaran bahasa Arab terdapat 4 keterampilan berbahasa, ${ }^{13}$ kategori pertama adalah keterampilan menyimak (al-istima '), awal dari keterampilan yang harus dipelajari oleh orang yang belajar bahasa. Mereka yang mempelajari bahasa asli atau bahasa asing harus menguasai keterampilan menyimak, tidak terkecuali saat belajar bahasa Arab.

kategori kedua adalah keterampilan berbicara (al-kalam), keterampilan yang berhubungan dengan bahasa lisan. Keterampilan berbicara menjadi keterampilan yang harus dikuasai setelah keterampilan menyimak karena sulit bagi penyandang pendengaran yang buruk untuk berbicara melalui mulut. Bahkan orang yang tidak dapat mendengarnya tidak akan pernah berbicara dalam bahasa yang dapat dimengerti orang lain. Kategori ketiga adalah keterampilan membaca (alqiro'ah), keterampilan yang berkaitan dengan pemahaman seseorang tentang teks tertulis. Kegiatan memahami isi pikiran orang lain dalam bentuk tertulis tentunya berbeda dengan kegiatan memahami isi pikiran orang lain secara langsung melalui kegiatan lisan dan menyimak. Hal ini dikarenakan ketika seseorang melakukan percakapan, tidak hanya menggunakan mulutnya sebagai tempat berbicara, tetapi juga memiliki faktor lain yang dapat membuat lawan bicara paham, seperti bahasa tubuh yang ditampilkan saat berbicara. ${ }^{14}$ Dengan melafalkan atau mencernanya dalam hati. Kategori keempat adalah keterampilan menulis (al-kitabah), Menulis merupakan kegiatan menyuntikkan ide ke dalam karya yang dapat pembaca pahami. Dalam menulis seseorang juga harus memperhatikan aspek lain, seperti menguasai generalis (kosakata), qowaid (tata bahasa),

9 Oleh Nunu Mahnun, “(Kajian terhadap Langkah-langkah Pemilihan Media dan Implementasinya dalam Pembelajaran)" 37, no. 1 (2012): 9.

10 Tohirin, Psikologi pembelajaran pendidikan agama Islam: berbasis intergrasi dan kompetensi (PT RajaGrafindo Persada, 2005), 7.

11 Oemar Hamalik, Kurikulum dan pembelajaran (Jakarta: Bumi Aksara, 1995), 36.

12 Mohammad Thoha, "Pembelajaran Bahasa Arab Dengan Pendekatan Manajemen Berbasis Sekolah," OKARA: Jurnal Bahasa dan Sastra 6, no. 1 (2012).

${ }^{13}$ Abdul Wahab Rosyidi dan Mamlu'atul Ni'mah, Memahami Konsep Dasar Pembelajaran Bahasa Arab (UIN-Maliki Press, 2011), 87.

14 Ali Mustofa, "Etika Pemberitaan Partai Politik di Televisi (Kasus Pemberitaan Partai Demokrat di Metro Tv dan Tv One)," Jurnal Ilmiah Komunikasi Makna 3, no. 1 (2021): 15-24. 
balaghah (sastra) dan memilih kamus yang sesuai. Ketika seseorang menulis, semua aspek tersebut harus ada, karena aktivitas menulis merupakan aktivitas yang diperlukan untuk memberikan pemahaman kepada orang lain yang tidak langsung berhadapan dengan isi tulisannya.

\section{Media pembelajaran bahasa Arab berbasis online}

\section{a. Definisi}

Istilah daring merupakan sebuah singkatan dari penggabungan kata "dalam jaringan" yang mana istilah ini mempunyai makna suatu kegiatan yang dilakukan secara online atau memanfaatkan jaringan internet. Jika sistem daring digabungkan dengan pembelajaran maka mempunyai makna suatu pembelajaran yang berlangsung secara online. Pembelajaran daring merupakan pelaksanaan sebuah kelas pembelajaran dalam jaringan yang mempunyai target luas dan kuat yang memanfaatkan beberapa teknologi multimedia seperti halnya streaming video, voice note, email, telepon dan lain sebagainya. ${ }^{15}$ Alimuddin \& Nadjib mengemukakan bahwasanya penggunaan e-learning bertujuan untuk mengirimkan pengetahuan ataupun informasi yang digunakan untuk meningkatkan keterampilan. Dalam penggunaan e-learning sebagai rujukannya adalah pada penggunaan teknologi internet. ${ }^{16}$ Penggabungan atau kolaborasi kegiatan belajar mandiri dengan simulasi dan permainan menggunakan daring membuat pembelajaran menjadi efektif karena peserta didik dapat berlatih dan melakukan umpan balik. ${ }^{17}$

Dari beberapa definisi dan penjelasan di atas dapat disimpulkan bahwasanya pembelajaran daring merupakan sebuah akronim dari pembelajaran dalam jaringan. Pembelajaran ini dilakukan secara digital atau tidak langsung bertatap muka. Pembelajaran daring dapat digunakan dalam kondisi yang darurat atau ketika tidak boleh dilakukan pembelajaran secara langsung di kelas.

\section{b. Karakteristik Pembelajaran Daring}

Pembelajaran daring memiliki beberapa ciri-ciri atau karakteristik. Menurut Tung dalam Mustofa dkk, memaparkan ciri-ciri pembelajaran daring sebagai berikut:18

1) Informasi disampaikan berupa teks, gambar dan berbagai elemen multimedia

2) Komunikasi dilakukan melalui video konferensi, berkirim pesan di kelas online atau diskusi di forum kelas

15 Eko Kuntarto, "Keefektifan model pembelajaran daring dalam perkuliahan bahasa Indonesia di perguruan tinggi," Indonesian Language Education and Literature 3, no. 1 (2017): 99-110.

${ }^{16}$ Alimuddin Alimuddin dan Muhammad Nadjib, "Intensitas Penggunaan E-learning dalam Menunjang Pembelajaran Mahasiswa Program Sarjana (S1) di Univeristas Hasanuddin," KAREBA: Jurnal Ilmu Komunikasi 4, no. 4 (2016): 387-98.

17 A. R. Kartika, “Model Pembelajaran Daring," Journal of Early Childhood Care \& Education 27 (2018).

18 Mokhamad Iklil Mustofa dkk., "Formulasi Model Perkuliahan Daring Sebagai Upaya Menekan Disparitas Kualitas Perguruan Tinggi," Walisongo Journal of Information Technology 1, no. 2 (20 Desember 2019): 151, https://doi.org/10.21580/wjit.2019.1.2.4067. 
3) Kegiatan dilakukan pada waktu dan ruang kelas digital

4) Pembaharuan informasi menjadi lebih mudah, karena bisa dilakukan setiap saat

5) Interaksi antara peserta didik dan fasilitator menjadi meningkat, karena terjadi proses umpan balik.

6) Dapat digunakan dalam kelas formal maupun nonformal

7) Penggunaan sumber belajar menjadi lebih bervariasi

Selain ciri-ciri di atas, menurut Peraturan Menteri Pendidikan dan Kebudayaan (PERMENDIKBUD) nomor 109 tahun 2013 ciri-ciri dari pembelajaran daring antara lain:

1) Pembelajaran daring merupakan pembelajaran yang dilakukan di luar kelas/ jarak jauh dengan menggunakan media komunikasi

2) Pembelajaran daring dilakukan secara e-learning atau pembelajaran berbasis elektronik. Pembelajaran ini memungkinkan peserta didik untuk mengakses informasi dimanapun dan kapanpun selama terhubung dengan jaringan informasi atau internet

3) Penggunaan sumber belajar disesuaikan dengan media informasi yang dikemas dengan berbasis teknologi sehingga lebih mudah disampaikan dalam proses pembelajaran daring

4) Pembelajaran daring dilakukan oleh peserta didik dengan mandiri menggunakan teknologi informasi dan komunikasi yang padu atau yang telah disesuaikan dengan materi dan jenjang tingkatannya.

5) Pembelajaran daring bersifat terbuka yang diselenggarakan secara fleksibel mulai dari penyampaian, pemilihan program studi, materi, jenjang/ tingkatan, penyelesaian program, pendidikan tanpa batas usia, tahun ijazah, latar belakang bidang studi, waktu studi, tempat dan cara belajar serta masa evaluasi hasil belajarnya.

Dari beberapa penjelasan mengenai ciri-ciri/ karakteristik pembelajaran daring di atas bisa disimpulkan bahwasanya karakteristik pembelajaran daring yaitu menggunakan media yang berbasis elektronik, pembelajaran daring juga lebih fleksibel dari segi waktu dan tempat, karena informasi dapat diakses dimanapun dan kapanpun dan pembelajaran daring juga bersifat lebih terbuka.

\section{c. Manfaat Pembelajaran Daring}

Pembelajaran daring mempunyai beberapa manfaat, seperti halnya yang disebutkan oleh Bilfaqih dan Qomarudin antara lain: ${ }^{19}$

1) Dengan memanfaatkan multimedia dalam pembelajaran dapat meningkatkan kualitas pendidikan dan pelatihan yang efektif. 2015), 4 .

19 Yusuf Bilfaqih dan M. Nur Qomarudin, Esensi Penyusunan Materi Pembelajaran Daring (Deepublish, 
2) Pendidikan menjadi mudah untuk dijangkau dan kualitas penyelenggaraan pendidikan dalam jaringan dapat meningkat.

3) Biaya penyelenggaraan pendidikan menjadi lebih berkualitas dan terjangkau, karena melalui pemanfaatan sumber daya bersama.

Kemudian menurut Hadisi dan Muna, manfaat pembelajaran daring adalah sebagai berikut: 20

1) Belajar menjadi lebih fleksibilitas, dikarenakan peserta didik dapat mengakses materi secara berulang-ulang kapanpun sesuai dengan yang dikehendakinya

2) Komunikasi dengan guru/ fasilitator menjadi lebih mudah dan bisa dilakukan setiap saat, sehingga penguasaan materi peserta didik menjadi meningkat

Dari penjelasan mengenai manfaat pembelajaran daring di atas dapat disimpulkan bahwasanya dengan adanya kemajuan teknologi dibidang informasi dan komunikasi, kualitas pembelajaran menjadi meningkat, dikarenakan interaksi ataupun penyampaian materi antara pendidik dan peserta didik menjadi lebih mudah. Pembelajaran bisa dilakukan kapanpun dan dimanapun selama terhubung internet serta jangkauan pendidikan menjadi lebih luas.

\section{d. Kelebihan Pembelajaran Daring}

Dengan adanya teknologi informasi yang berkembang pesat membuat penyampaian informasi menjadi lebih mudah. Tentunya selain itu juga mempunyai kekurangan dan kelebihannya masing-masing. Untuk itu ada beberapa kelebihan dan kekurangan pembelajaran daring menurut Hadisi dan Muna, sebagai berikut: 21

1) Dari segi biaya, e-learning lebih terjangkau atau dapat lebih menghemat biaya, karena mampu mengurangi biaya pelatihan berupa penyediaan alat tulis, proyektor dan kebutuhan-kebutuhan kelas lainnya.

2) Dari segi waktu, e-learning lebih fleksibel. Karena, peserta didik dapat menyesuaikan penggunaan waktu untuk belajar dikarenakan materi/ informasi dapat diakses kapanpun sesuai dengan yang dikehendakinya.

3) Dari segi tempat, e-learning juga lebih fleksibel. Karena peserta didik dapat mengakses materi/ informasi dimanapun dengan syarat jaringan internet masih terhubung.

\section{Metode Penelitian}

Dalam melakukan penelitian ini untuk meningkatkan pemahaman, penulis akan menguraikan sebagai berikut:

20 La Hadisi dan Wa Muna, "Pengelolaan teknologi informasi dalam menciptakan model inovasi pembelajaran (e-learning),” Al-TA’DIB: Jurnal Kajian Ilmu Kependidikan 8, no. 1 (2015): 117-40.

${ }^{21}$ Hadisi dan Muna, 130. 


\section{Jenis Penelitian}

Penelitian ini menggunakan metode penelitian kualitatif deskriptif. Penelitian kualitatif adalah suatu metode penelitian yang didasarkan pada filosofi positivisme, digunakan untuk memeriksa kondisi benda-benda alam dan untuk melakukan teknologi pengambilan sampel sumber data yang ditargetkan. Tujuan penelitian kualitatif adalah menemukan makna dibalik data dan menemukan kebenaran empiris. ${ }^{22}$ Tujuan penelitian kualitatif tidak hanya mendeskripsikan, tetapi juga eksplorasi dan penjelasan. Dalam penelitian ini peneliti menggunakan penelitian kualitatif deskriptif. penelitian kualitatif deskriptif digunakan peneliti untuk memperoleh informasi yang berkaitan dengan aspek sosial yang terjadi di dalam proses pembelajaran bahasa Arab berbasis $E$ learning di MAN 3 Tulungagung.

\section{Sumber Data}

Saat melakukan penelitian, selain memilih pertanyaan penelitian, satu hal yang harus diperhatikan kembali adalah ketersediaan sumber data. Selain itu, dalam penelitian kualitatif perlu dipahami fenomena atau gejala sosial. Sumber data dalam penelitian adalah subjek dari mana data tersebut dapat diperoleh. Oleh karena itu perlu dilakukan pencarian data berdasarkan pembelajaran bahasa Arab online yang digunakan di MAN 3 Tulungagung, sehingga penulis akan mengumpulkan data melalui wawancara.

Dalam penelitian ini, objek penelitiannya adalah penerapan E-learning dalam pembelajaran bahasa Arab di situasi pandemi terkait dengan manfaatnya beserta dengan faktor-faktor yang menjadi pendorong dan penghambat dalam penggunaanya. Sumber data/ subjek dalam penelitian ini adalah guru pengampu mata pelajaran bahasa Arab kelas X MAN 3 Tulungagung dan seluruh siswa kelas X IPS 3 di MAN 3 Tulungagung yang berjumlah 32 anak. Guru pengampu mata pelajaran bahasa Arab dibutuhkan untuk menggali informasi terkait dengan penggunaan E-learning yang digunakan dalam proses belajar mengajar daring, sedangkan siswa kelas X dibutuhkan untuk menggali informasi terkait peran pemanfaatan media E-learning dalam proses pembelajaran bahasa Arab. Dengan demikian peneliti dapat memperoleh informasi terkait penerapan E-learning dalam pembelajaran bahasa Arab yang digunakan di MAN 3 Tulungagung terkait dengan faktor pendorong dan penghambatnya, sehingga ke depannya segala yang menjadi penghambat dapat dikurangi dan dibenahi.

\section{Teknik Pengumpulan Data}

Dalam penelitian kualitatif teknik pengumpulan datanya adalah dengan cara triangulasi (kombinasi), dan teknologi analisis datanya induktif /kualitatif. Hasil penelitian kualitatif lebih

${ }^{22}$ Moh Kasiram, Metodologi penelitian: Kualitatif-kuantitatif(Uin-Maliki Press, 2010), 177. 
menekankan pada generalisasi. ${ }^{23}$ Adapun dalam penelitian ini teknik pengumpulan data yang digunakan peneliti adalah observasi, wawancara dan dokumentasi. Observasi yang dilakukan peneliti menghabiskan waktu 3 pekan, terdiri dari observasi awal dan observasi proses penerapan E-learning dalam pembelajaran bahasa Arab. Pihak yang diwawancarai peneliti ada 2 yaitu siswa kelas X IPS 3 MAN 3 Tulungagung dan guru mata pelajaran bahasa Arab kelas X. Kemudian yang terakhir dokumentasi terkait data pendukung berupa foto penelitian dan media E-learning yang digunakan dalam pembelajaran bahasa Arab. Setelah semua data terkumpul peneliti melakukan analisis data dengan menggunakan teknik triangulasi. Data dari teknik inilah yang merupakan hasil dari penelitian ini.

\section{Teknik Analisis Data}

Data yang dapatkan dari penerapan E-learning dalam pembelajaran bahasa Arab di MAN 3 Tulungagung selanjutnya dilakukan analisis dengan tahapan sebagai berikut:

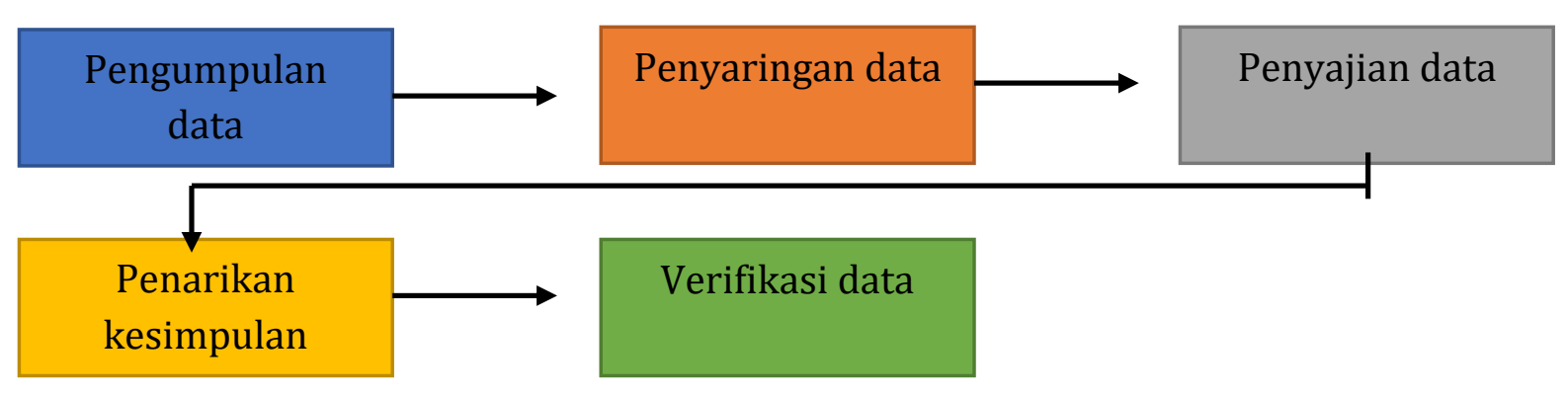

Gambar 1. Proses Analisis Data

Pertama: pada tahap ini peneliti melakukan pengumpulan data dan berbagai informasi yang berhubungan dengan penerapan e-learning dalam pembelajaran bahasa Arab di MAN 3 Tulungagung. Kedua: setelah semua data dan informasi terkumpul, peneliti melakukan penyaringan informasi dan menyesuaikan informasi yang telah didapat dengan observasi lapangan dan dokumentasi. Ketiga: pada tahap ini peneliti melakukan penyajian data yang telah diklasifikasikan. Keempat: peneliti melakukan penarikan kesimpulan terkait dengan informasi yang telah disajikan. Kelima: pada tahap ini peneliti memverifikasi data dengan menggunakan data selain data inspeksi atau membandingkannya dengan data yang dihasilkan melalui suatu rangkaian kegiatan.

23 Sugiyono, Metode penelitian pendidikan pendekatan kuantitatif, Kualitatif, dan R\&D (Bandung: Alfabeta, 2012), 15. 


\section{Hasil dan Pembahasan}

\section{Pembelajaran bahasa Arab berbasis online}

Dari observasi dan wawancara dan pengumpulan data diperoleh hasil bahwasanya dalam menunjang keberhasilan pembelajaran bahasa Arab di tengah situasi pandemi covid-19 yang masih mewabah, MAN 3 Tulungagung menerapkan pembelajaran berbasis online atau biasa disebut $E$ learning. Pembelajaran berbasis online digunakan untuk menggantikan peran pembelajaran di dalam kelas. Pembelajaran berbasis online yang digunakan di MAN 3 Tulungagung adalah dengan menggunakan berbagai macam media interaktif, mulai dari whatsapp, zoom meeting room, google classroom ebook learning, dan web base. Media pembelajaran berbasis online dapat disisipkan berbagai macam bentuk file, seperti tulisan, power point, excel, gambar, video, animasi, audio, dan lain-lain. Untuk lebih jelasnya dapat dilihat melalui link web base MAN 3 Tulungagung berikut: http://www.man3tulungagung.sch.id/halaman/detail/elearning-madrasah. Link tersebut memuat berbagai macam komponen kebutuhan pembelajaran mulai dari absensi, jumlah siswa, raport penilaian, kurikulum, monitoring, materi, dan masih banyak lagi. Selain itu juga digunakan sebagai ruang belajar online.

Media berbasis online tersebut digunakan di luar kelas sebagai bentuk pembelajaran daring. Hal tersebut dilakukan sampai batasan waktu yang belum ditentukan, seperti yang disarankan oleh pemerintah dalam mencegah penularan wabah virus corona demi mengurangi percepatan perkembangan virus corana wajib untuk menjaga jarak dan menghindari kerumunan orang. Dengan demikian E-learning diterapkan di seluruh pembelajaran di MAN 3 Tulungagung sampai batasan yang belum ditentukan.

Dalam pembelajaran daring guru memberikan penugasan dan pembelajaran mandiri secara online. Selain itu, siswa juga dapat berdiskusi terkait dengan materi yang diajarkan guru dengan lebih intensif. Terkait dengan pengumpulan tugas materi dapat dikirim melalui laman yang telah disediakan oleh guru di ruang belajar online. Dalam pembelajaran daring pelaksanaannya dapat dilakukan siswa di tempatnya masing-masing tanpa batas selama tersambung dengan jaringan. Untuk waktu pelaksanaannya disesuaikan dengan jadwal pembelajaran luring tetapi durasinya lebih dipersingkat yakni dari awalnya 1 jam pelajaran sama dengan 45 menit menjadi 1 jam sama dengan 25 menit. Namun, terkadang waktunya juga tidak ada batasan atau fleksibel. Dengan demikian diharapkan bagi siswa MAN 3 Tulungagung dengan adanya wabah virus covid ini dikarenakan pembelajaran bersifat online, maka siswa harus belajar dengan giat sebagaimana mestinya. Siswa dapat memanfaatkan ruang belajar online dengan maksimal agar tujuan pembelajaran bisa tercapai dengan baik. 


\section{Manfaat Penerapan Pembelajaran Bahasa Arab Berbasis Online}

Dari hasil penelitian diperoleh hasil bahwasanya siswa lebih fleksibel dalam hal belajar. Siswa dapat mengakses materi sendiri yang telah diajarkan oleh guru sebelumnya dan belajar lebih mudah bisa dilakukan setiap saat dan dimanapun selama terkoneksi internet. Sumber belajar juga lebih luas dan banyak tidak hanya mengandalkan bahan ajar dari sekolah, melainkan bisa dari ebook, google, artikel, jurnal atau yang lainnya. Begitu juga yang dirasakan oleh guru, pembelajaran menjadi lebih fleksibel karena penyampaian pembelajaran bisa sambil duduk di kantor. Guru juga bisa lebih dekat dengan siswa, karena bisa lebih intens dalam hal memperhatikan peserta didik dalam belajar. Dalam penyelenggaraan pendidikan pembelajaran berbasis online juga lebih ringan biayanya, karena tidak perlu menyiapkan media pembelajaran yang bersifat konvensional seperti penyediaan laboratorium, proyektor, board marker, dan lain-lain. Pembelajaran berbasis online lebih simpel cukup dengan ketersediaan jaringan internet dan perangkat komunikasi seperti gadget atau pc.

\section{Faktor-Faktor Pendorong dan Penghambat Keberhasilan Pembelajaran Berbasis Online}

Dalam melakukan penelitian di kelas X IPS 3 MAN 3 Tulungagung, setelah dilakukan pengamatan dan wawancara terdapat beberapa aspek/ faktor-faktor yang menjadi pendorong dan penghambat keberhasilan pembelajaran berbasis online, antara lain sebagai berikut:

a. Jaringan internet, dengan jaringan internet yang memadai/ tidak lemah pembelajaran online dapat tersampaikan dengan baik. Terlebih lagi media pembelajaran berbasis online yang bersifat langsung seperti zoom yang seyogyanya membutuhkan internet kuat akan sangat terganggu jika jaringan internet lemah. Kalau untuk pembelajaran yang bersifat tidak langsung mungkin tidak terlalu membutuhkan jaringan kuat.

b. Gadget atau pc, tanpa ada media yang menjalankan maka proses pembelajaran berbasis online tidak dapat diakses dengan baik. Tentunya gadget/pc harus sesuai dengan kebutuhan aplikasi saat ini, dengan kata lain alat komunikasi harus memadai. Jika alat komunikasi tidak memadai maka akan terhambat atau bahkan tidak dapat menjalankan aplikasi yang digunakan untuk pembelajaran.

c. Guru/ fasilitator, sebagai orang yang menjalankan media atau aplikasi harus memiliki keahlian dalam hal tersebut, dengan kata lain guru tidak boleh gaptek. Jika guru tidak dapat menjalankan pembelajaran online dengan baik maka proses penyampaian materi tidak dapat tersampaikan kepada siswa.

d. Siswa, selain guru siswa juga harus bisa menjalankan media atau aplikasi, agar ketika penyampaian materi siswa dapat mengakses kegiatan pembelajaran dengan semestinya. Jika tidak, sudah dapat dipastikan siswa akan ketinggalan materi pembelajaran. 
e. Komunikasi antara guru, orang tua dan murid. Pelaksanaan pembelajaran tidak akan sukses tanpa ada kontrol dari guru dan orang tua kepada siswa. Sehingga ketiganya ini harus saling bersinergi dan berinteraksi terlibat dengan baik dalam pelaksanaan pembelajaran. Apalagi dalam situasi pandemi yang mana guru tidak bisa memonitoring langsung, jadi peran orang tua sangatlah penting dalam mengontrol siswa ketika berada di rumah.

Hasil wawancara mengungkap beberapa pengalaman siswa dalam menggunakan pembelajaran online dapat diringkas sebagaimana tabel 1. Ada yang bahkan belum berpengalaman, dan ada yang tidak memiliki alat komunikasi. Mereka yang telah merasakan pengalaman belajar online merasa terbantu untuk proses belajar. Meski demikian perlu adanya adaptasi dan pembiasaan.

Tabel 1. Pengalaman Siswa Menggunakan Aplikasi Pembelajaran Onlie

\begin{tabular}{|c|c|}
\hline PENGALAMAN SISWA & KETERANGAN \\
\hline $\begin{array}{l}\text { Sebelumnya ya kak, saya belum pernah menggunakan aplikasi } \\
\text { pembelajaran berbasis online apapun (YAFA, N1) }\end{array}$ & \\
\hline $\begin{array}{l}\text { Saya dulu ketika awal penerapan pembelajaran berbasis online } \\
\text { agak mengalami kesulitan, dikarenakan pada saat itu situasinya } \\
\text { mendadak dan juga minimnya sosialisasi mengenai penerapan } \\
\text { pembelajaran berbasis online (YAFA, N1) }\end{array}$ & $\begin{array}{l}\text { Hambatan } \begin{array}{l}\text { pencapaian } \\
\text { penerapan pembelajaran } \\
\text { online }\end{array} \\
\text { p }\end{array}$ \\
\hline $\begin{array}{l}\text { Saya dulu kesulitan ketika pembelajaran dialihkan menjadi online, } \\
\text { dikarenakan pada saat itu hp saya masih jadul belum bisa } \\
\text { mengakses aplikasi-aplikasi pembelajaran online, sehingga ketika } \\
\text { kelas online kerap kali saya meminjam ke kakak saya (LDR, N2) }\end{array}$ & $\begin{array}{l}\text { Tidak mempunyai alat } \\
\text { komunikasi yang memadai }\end{array}$ \\
\hline $\begin{array}{l}\text { Belajar online menurut saya ada serunya, karena saya } \\
\text { mendapatkan banyak pengalaman baru yang sebelumnya belum } \\
\text { pernah saya dapatkan ketika pembelajaran di dalam kelas (FN, N3) }\end{array}$ & Membantu \\
\hline $\begin{array}{l}\text { Awalnya saya merasa malu dan canggung ketika pembelajaran di } \\
\text { kelas online menggunakan zoom karena harus menampilkan } \\
\text { gambar saya, tapi lama-kelamaan saya jadi terbiasa (FN, N3) }\end{array}$ & $\begin{array}{l}\text { Pembelajaran online butuh } \\
\text { adaptasi dan pembiasaan }\end{array}$ \\
\hline $\begin{array}{l}\text { Kalau menurut saya ya kak, jaringan internet yang cepat itu sangat } \\
\text { berpengaruh ketika mengakses pembelajaran, saya pernah } \\
\text { kebingungan ketika jaringan internet saya mati ketika } \\
\text { pembelajaran di kelas online (DPS, N4) }\end{array}$ & $\begin{array}{l}\text { Faktor yang mendorong } \\
\text { pencapaian pembelajaran } \\
\text { online }\end{array}$ \\
\hline
\end{tabular}




\section{E. Kesimpulan}

Problematika dalam situasi pandemi saat ini mengharuskan inovasi yang mutakhir mengenai pelaksanaan pembelajaran. Kegiatan pembelajaran yang seharusnya berada di dalam kelas menjadi ditiadakan dan diganti pembelajaran di dalam jaringan. Seperti halnya di MAN 3 Tulungagung dalam pelaksanaan kegiatan pembelajaran bahasa Arab menggunakan media web base learning untuk mencapai tujuan pembelajaran yang dikehendaki. Penerapan pembelajaran bahasa Arab berbasis online sangat tepat digunakan, di sisi lain siswa juga bisa tetap memperoleh materi walaupun tidak dengan tatap muka secara langsung. Tetapi disisi lain juga terdapat beberapa kendala dalam pelaksanaannya, ada beberapa siswa yang mengeluhkan tentang jaringan internet yang sering terjadi masalah, ada juga beberapa siswa yang kurang begitu memahami dan kurang terbiasa menggunakan media online dalam pembelajaran. Sehingga mengharuskan mereka untuk belajar dan menyesuaikan diri dengan pembelajaran berbasis online.

\section{Daftar Rujukan}

Alimuddin, Alimuddin, dan Muhammad Nadjib. "Intensitas Penggunaan E-learning dalam Menunjang Pembelajaran Mahasiswa Program Sarjana (S1) di Univeristas Hasanuddin." KAREBA: Jurnal Ilmu Komunikasi 4, no. 4 (2016): 387-98.

Atwi, Suparman. “Guru Sebagai Arsitek Pembelajaran Sepanjang Waktu: Mungkin?” Dalam Seminar Universitas Terbuka. Jakarta: Universitas Terbuka, 2013.

Bilfaqih, Yusuf, dan M. Nur Qomarudin. Esensi Penyusunan Materi Pembelajaran Daring. Deepublish, 2015.

Hadisi, La, dan Wa Muna. "Pengelolaan teknologi informasi dalam menciptakan model inovasi pembelajaran (e-learning)." Al-TA'DIB: Jurnal Kajian Ilmu Kependidikan 8, no. 1 (2015): 117-40.

Hamalik, Oemar. Kurikulum dan pembelajaran. Jakarta: Bumi Aksara, 1995.

Hubbard, Philip. "Making a Case for Learner Training in Technology Enhanced Language Learning Environments." CALICO Journal 30, no. 2 (31 Mei 2013): 163-78. https://doi.org/10.11139/cj.30.2.163-178.

Kartika, A. R. “Model Pembelajaran Daring.” Journal of Early Childhood Care \& Education 27 (2018).

Kasiram, Moh. Metodologi penelitian: Kualitatif-kuantitatif. Uin-Maliki Press, 2010.

Khomsah, Ahmad Fadilah, dan Muhammad Imron. "Pembelajaran bahasa Arab melalui kolaborasi metode questioning dan media kahoot." Tarbiyatuna: Jurnal Pendidikan Ilmiah 5, no. 1 (2020): 99-118.

Kosim, Nanang, Imam Turmudi, Novy Maryani, dan Abdul Hadi. "Pembelajaran bahasa Arab melalui daring: Problematika, solusi dan harapan." Work From Home, 2020. 
Kuntarto, Eko. "Keefektifan model pembelajaran daring dalam perkuliahan bahasa Indonesia di perguruan tinggi." Indonesian Language Education and Literature 3, no. 1 (2017): 99-110.

Mahnun, Oleh Nunu. "(Kajian terhadap Langkah-langkah Pemilihan Media dan Implementasinya dalam Pembelajaran)" 37, no. 1 (2012): 9.

Mustofa, Ali. "Etika Pemberitaan Partai Politik di Televisi (Kasus Pemberitaan Partai Demokrat di Metro Tv dan Tv One)." Jurnal Ilmiah Komunikasi Makna 3, no. 1 (2021): 15-24.

Mustofa, Mokhamad Iklil, Muhammad Chodzirin, Lina Sayekti, dan Roman Fauzan. "Formulasi Model Perkuliahan Daring Sebagai Upaya Menekan Disparitas Kualitas Perguruan Tinggi." Walisongo Journal of Information Technology 1, no. 2 (20 Desember 2019): 151. https://doi.org/10.21580/wjit.2019.1.2.4067.

Noh, Mohd Aderi Che, Haslina Abdullah, dan Nor Hayati Fatmi Talib. "Knowledge and Learning Teachers Toward The Implementation of Guided Inquiry Approach in Aqidah Curriculum." Al-Hayat: Journal of Islamic Education 3, no. 2 (2019): 126-39.

Riqza, Meidiana Sahara, dan M. Muassomah. "Media Sosial untuk Pembelajaran Bahasa Arab pada Masa Pandemi: Kajian Kualitatif Penggunaan WhatsApp pada Sekolah Dasar di Indonesia." Alsina: Journal of Arabic Studies 2, no. 1 (2020): 71-94.

Rosyidi, Abdul Wahab, dan Mamlu'atul Ni'mah. Memahami Konsep Dasar Pembelajaran Bahasa Arab. UIN-Maliki Press, 2011.

Sugiyono. Metode penelitian pendidikan pendekatan kuantitatif, Kualitatif, dan R\&D. Bandung: Alfabeta, 2012.

Thoha, Mohammad. "Pembelajaran Bahasa Arab Dengan Pendekatan Manajemen Berbasis Sekolah.” OKARA: Jurnal Bahasa dan Sastra 6, no. 1 (2012).

Tohirin. Psikologi pembelajaran pendidikan agama Islam: berbasis intergrasi dan kompetensi. PT RajaGrafindo Persada, 2005.

Vadhillah, Syukra, Alimin Alimin, dan Suharmon Suharmon. "Problematika Pembelajaran Bahasa Arab di Madrasah Aliyah Negeri (MAN) Batu Mandi Tilatang Kamang." Arabia 8, no. 1 (2017).

Wikipedia. "Teknologi." Dalam Wikipedia bahasa Indonesia, ensiklopedia bebas, 24 Juni 2021. https://id.wikipedia.org/w/index.php?title=Teknologi\&oldid=18561960. 